International Journal of Advanced Geosciences, $7(2)(2019) 124-128$
International Journal of Advanced Geosciences
SPC
Website: www.sciencepubco.com/index.php/IJAG
Research paper

\title{
A brief communication of shispar glacier surge in 2018, hunza river basin, Pakistan
}

\author{
Alamgeer Hussain * \\ Secretariat of Agriculture, Livestock and Fisheries Department Gilgit Baltistan \\ *Corresponding author E-mail: alamgeerh@gmail.com
}

\begin{abstract}
Glacier surging is a common phenomenon in the Karakoram region, but the driving mechanisms, their occurrence and its relation to a changing climate remain are unclear. In this study, we use Sentinel imagery to quantify advancement of the Shispar glacier during a surge in 2018. Results reveal that Shispar glacier starts rapid surging from Jun 2018. The peak surge is in August 2018. Our data reveal that glacier dammed the Hassanabad stream as result lake formation in upstream area and drainage of the lake also blocked. The surging is continuing and size of newly formed glacier lake is also increasing day by day. Currently, the inflow to lake is very low due to low melting (negative temperature) from the upstream glacier. This inflow of glacier meltwater will be an increase in the summer season, which may grow in lake size and could pose threats to downstream settlements and infrastructure (irrigation channels, powerhouses and bridge at Karakoram Highway (KKH) in the case of a sudden breach in the form of glacial lake outburst flood (GLOF). Currently the damages the powerhouse channel and damage the irrigation channel of Aliabad Hunza. This study recommended that there is a need for monitoring of glacier lake size and blockage area using remote sensing data i.e. satellite images and UAV.
\end{abstract}

Keywords: Satellite Images; GLOF; KKH; Glacier.

\section{Introduction}

Surging glaciers are not evenly spread in glaciate regions around the world's, but take place frequently in specific circumstances [Sevestre, H. and Benn, D. I, 2015]. Glacier surges have been documented frequently since the end of the 19th century at numerous locations in the Karakoram region. There are two general mechanisms govern the surges of glaciers: increase in ice mass in accumulation zone of glacier causing: increased basal shear stress resulting in till deformation at the glacier bed referred to as the thermal switch hypothesis [Clarke et, al, 1984 \& Quincey 2011] and (b) enlarge of drainage channel through collapse of glacier surface, this drainage water work as lubrication of the glacier bed referred to as the hydrological switch hypothesis [Kamb, B. 1987]. Studies report surges in the region being controlled by both the first [Mayer et al 2011]. Throughout world glacier ice mass are in recession, while the Karakoram glaciers are in advancing form, this anomalous behaviour of ice mass balance of glaciers have received considerable scientific attention [Kääb, A, et al. 2015] and the large number of surging glaciers [Paul et al. 2015F Frey, H et al. 2017 \& Bolch, T et al. 2017].

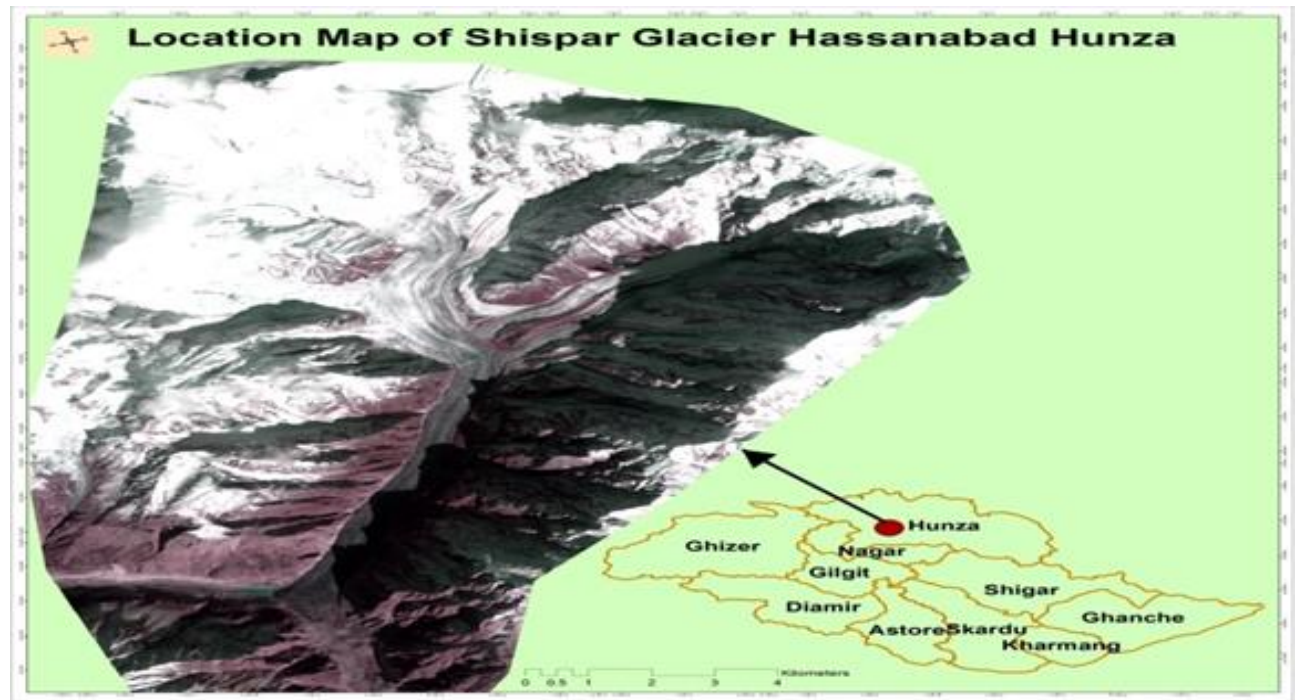

Fig. 1: Location map of Shispar Glacier 
Khurdopin glacier is one of the known, have been documented to occur since the late 1800s and the most recent surges occurred in 1979 and 1999 [Copland, L. et al. 2011, Quincey, D. J. et al 2014, Iturrizaga, L et al 2005, Steiner, J. et al 2018 and Rankl, M. et al 2015]. There is a need for better understood related Surging activity to advance our knowledge of ice dynamic processes as well as glacially driven erosion and sediment transport in the region. Moreover, understanding of glacier surges is important as they may result in natural hazards in the form glacial lake outburst flood (GLOF) that are due to the formation of ice dams and potential blockage of rivers [Hussain, A et al 2018 \& Hussain. 2019].

Shispar Glacier, located in the Hassanabad watershed, district Hunza in northern Pakistan. (36॰2001800 N, 75॰280300 E), this glacier start surging in the month of May 2018, during the surge event the snout is pushed further into the valley and blocked the Hassanabad stream, resulting in an ice-dammed lake form upstream. In the region, a similar process has been observed and well documented for Kyagar Glacier [Round, V. 2017]. Therefore, these glacier advances have been only measured through velocity data from ground distinct features of a glacier, using both field observation and high-resolution satellite images. In this study, we are investigating the surge event in 2018 using current sentinel satellite imagery and field photographs. First, we calculate the surge distance and ice dam area using multi-temporal images through change detection techniques and manual delineation process.

\section{Material and methods}

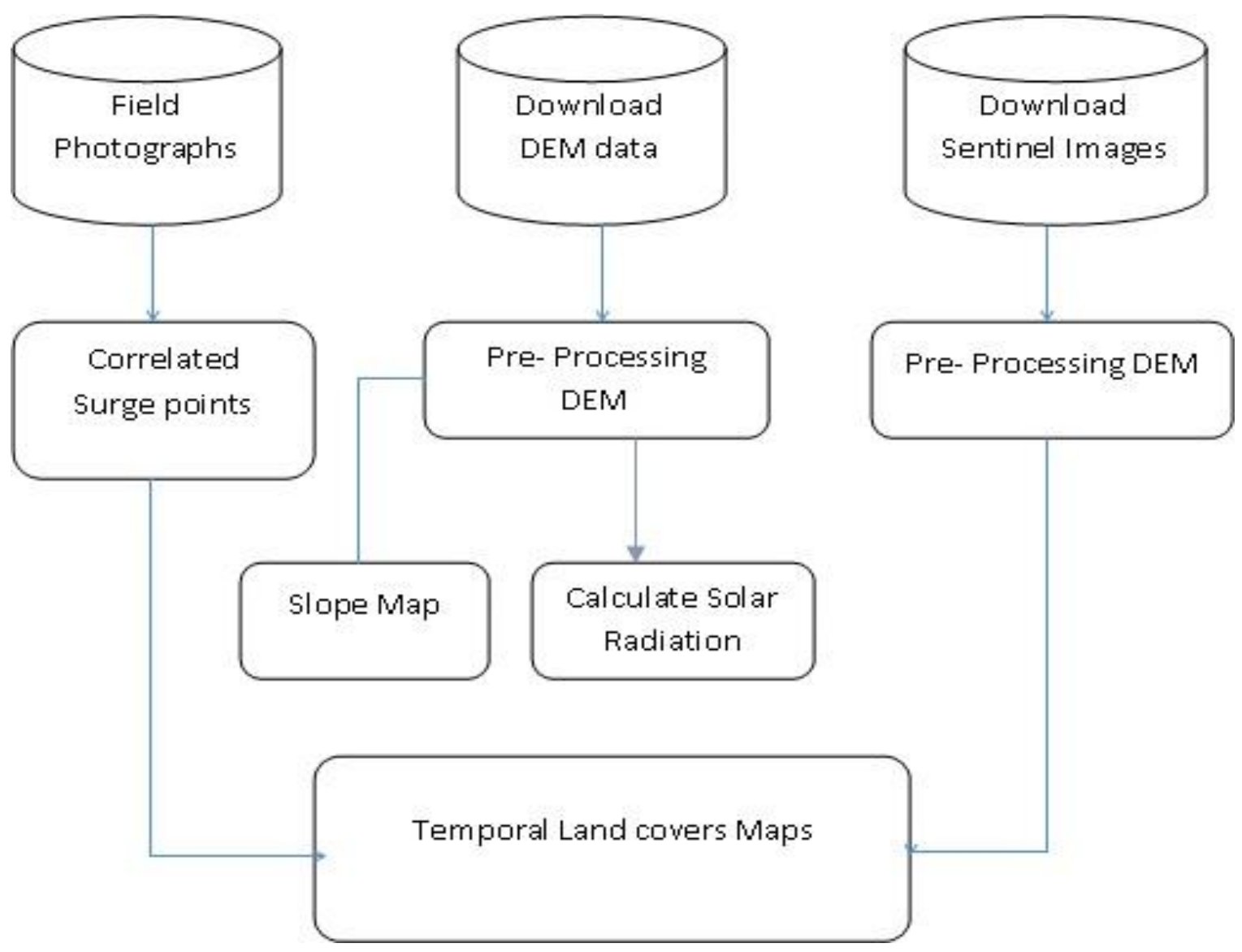

Fig. 2: Work Flow Diagram of Study.

To measure the temporal surge of Shispar glacier we use change detection technique couple with manual delineation of surge boundaries on pre and post sentinel images in Arc GIS environment. The ice deposit and lake area were measured by through manual delineation [ Altena, B. et al 2017, Damsgaard, A. 2015 \& Shean, D. 2016]. Sentinel images were preprocessed and clip with Shispar glacier boundary for further process. Causes of triggering mechanism investigate through analysis of Topographic factor (slope and aspect) in Arc GIS environment. The detail workflow diagram of the methodology is shown in (Figure:2).

\section{Results and discussion}

\subsection{Shispar glacier surge event}

Shispar glacier is approximately $16 \mathrm{~km}$ length, $0.8 \mathrm{~km}$, width and has an elevation range between $2500 \mathrm{~m}$ above mean sea level (a.s.l) in Hassanabad watershed (Figure:1). It is heavily debris-covered on the lower $7 \mathrm{~km}$ of the ablation zone and separate travelling of debris bands represent the surge-type of glacier exist up to $11 \mathrm{~km}$ from the terminus. To investigate the glacier advance distance, we have divided the glacier into three zones: pure snow covers $5 \mathrm{~km}$, snow and debris mixed cover $4 \mathrm{~km}$ and debris cover glacier $7 \mathrm{~km}$. We used a presurge sentinel image to mark the pre-surge boundary and measured the advance distance and deposit area on post surge image. The surge of Shispar observed on June 2018. From June to December 2018, $0.4 \mathrm{~km}$ length of glacier advance toward the valley. This surge blocked $1.09 \mathrm{~km}$ length of Hassanabad stream and 0.081 sq.km of the lake was formed between Shispar and Hassanabad glacier (Figure 3). Field photographs also show glacier tongue advancement and its impacts (Figure 4). 


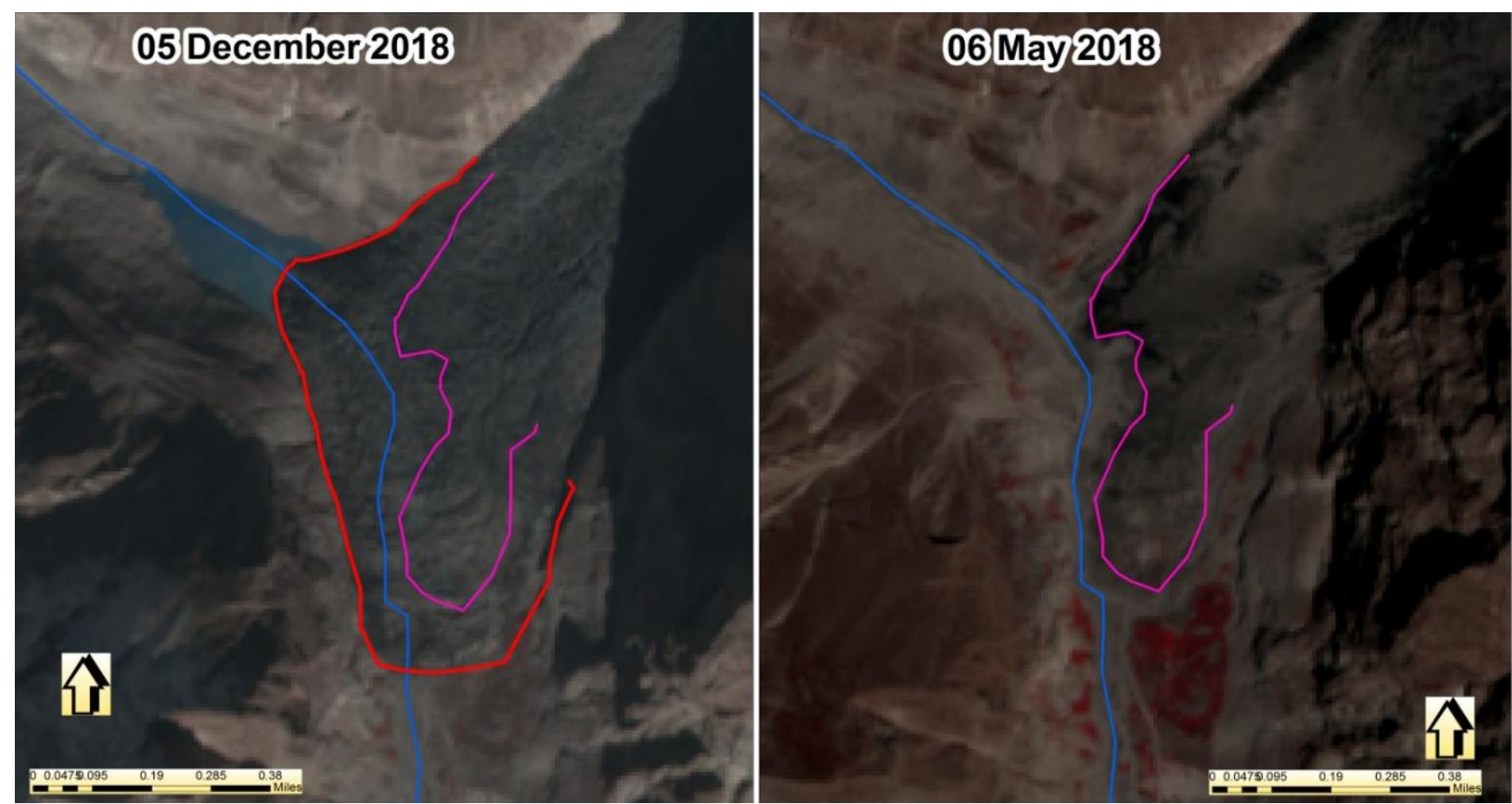

Fig. 3: Temporal View of Shispar Glacier Surge Hassanabad Hunza Karakoram Region, Pakistan.

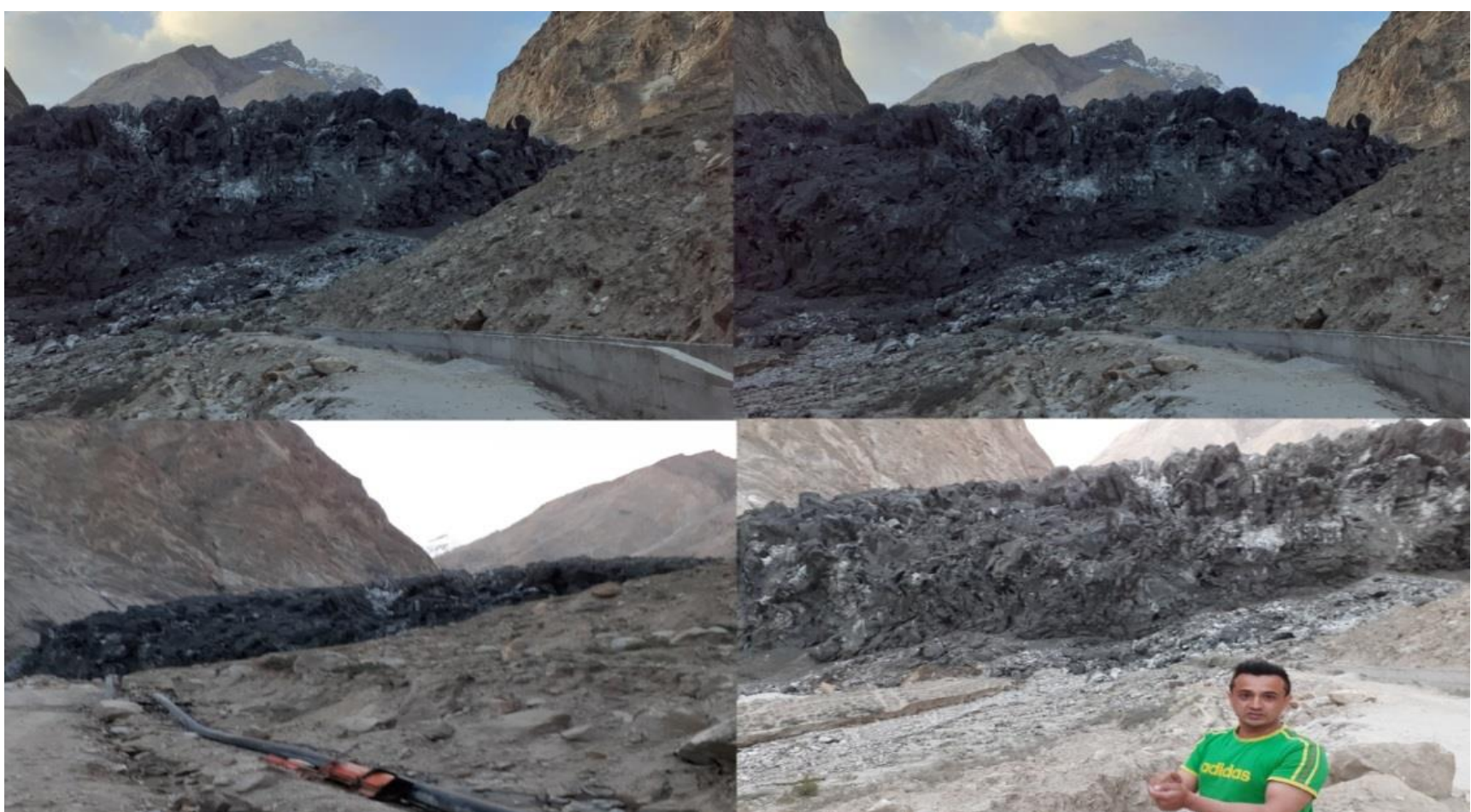

Fig. 4: Field Photos of Shispar Glacier Tongue. These Pictures Have Taken at May 10 2019, Show the Advanced Tongue of Shispar Glacier and Also Show the Power House and Irrigation Channels Damages.

The surging of a glacier is still occurring toward the valley. Current year heavy snowfalls occur from December in Hassanabad watershed. This snowfall increase ice mass in the accumulation zone of a glacier, it may accelerate the glacier advancement through increased basal shear stress. The causes of surge are due increase ice mass of accumulation zone and its steep slope. The lack of cloud free imagery or poor image quality does not always allow accurate identification of the onset, peak and termination of the surge.

\subsection{Glacier deposit and lake volume}

The surge of glacier also results in large amounts of displaced ice volume. This displaces of ice mass change the position of glacier snout. In Shispar glacier the terminus advance toward valley and blocked the river. The advance ice mass volume of Shispar glacier were calculated through intersecting of visually derived advance boundary with digital elevation model using functional surface tool in Arc GIS 10.2 platform. Due to this advances a lake was formed upstream area, which is grow day by day. We calculated the lake volume using Lake Boundary couple with elevation data (DEM) through functional surface tool in Arc GIS 10.2 environment. the results show that total 0.4 sq.km area were deposited through advancement and approximate 59.6 million cubic meter of ice volume were carried by glacier surge from June 2018 to till date the flakier still advancing toward downstream. 


\subsection{Hydrology and hazards}

Currently the tongue of the Shispar Glacier reaches across the main valley floor. As a result, the glacier has blocked the local Hassanabad stream, caused by the snout pushing towards the opposite rock of the watershed (Fig. 3 and 4). Nearly all of document lake drainage were not devastated and they have seldom caused damages downstream beyond eroded fields and damaged bridges (Hewitt and Liu, 2010; Iturrizaga, 2005). The height of advanced glacier tongue is 20 meter at the fringe and up to 180 meter on surging tongue. Total dammed length of Hassanabad stream is $1.09 \mathrm{~km}$ with advance area $0.40 \mathrm{sq} \mathrm{km}$. In September 2018, the lake formed above the blockage, increasing rapidly from $200 \mathrm{~m}$ length, it reached 500 meter at the beginning of December. The total area of lake is 0.081 sq.km and approximate lake depth is 5 meters; it increases day by day. We show the potential lake size reach beyond $1 \mathrm{~km}$ during the melt season of 2019. Such increase in lake size could cause devastating flood in case of collapse of glacier lake frontal moraine due to increase pressure of lake water.

\subsection{Topographic factor and solar insolation}

Topographic factor i.e. slop is calculated using elevation dataset (DEM) in Arc GIS environment. Slope range of Shispar glacier is in between 5 to 74 degree. Slop statistics of Shispar glacier: 0-15 degree covers 47\%, 16-25 degree cover 17.3\%, 25-35 degree cover 18.3\% and above 35 degree cover 17\%. $72 \%$ area of accumulation zone of glacier having above 25-degree slope, that why the ice mass pushing toward ablation as well as the terminus slope of glacier also favorable for surging. The solar insulation surface of glacier also reflects that more than $74 \%$ area of accumulation and ablation zone received maximum amount of light due to south east aspect. this light causes formation of large amount of small pounds at the surface of glacier in summer season which drain under the curves of glacier. This water work as lubricant as a result advancement of glacier toward Hassanabad stream (Figure: 5).

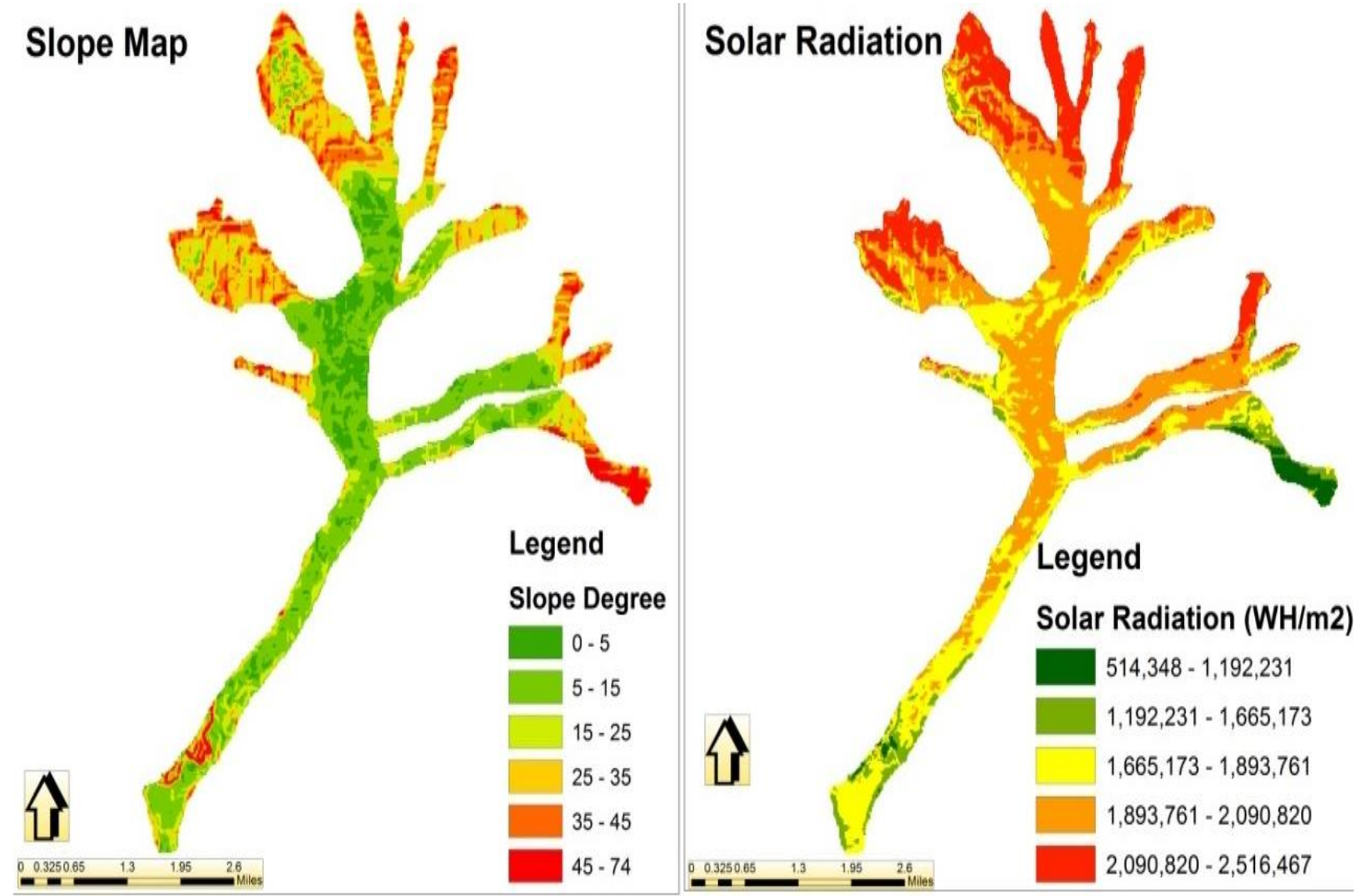

Fig. 5: Shows the Slope and Solar Insulation Surfaces of Shispar Glacier Surge Hassanabad Hunza Karakoram Region, Pakistan.

\section{Conclusion and recommendation}

The data collected and analyzed showed that the Shispar glacier first time surge and dammed the Hassanabad river while other glaciers like Khurdopin has blocked the river many time, relatively constant return period of a glacier surge of 20 years since the end of the 19th century, irrespective of a changing climate and surges of nearby glaciers [Hewitt, K. and Liu, J. 2010]. Surge of glacier result bring lot amount of ice mass downstream. In Shispar glacier snout advance $380.50 \mathrm{~m}$ length and blocked the stream in December 2018. The glacier still advancing downstream as well as lake size also increases day by day. The Satellite images and field data shows that there are many curves exist in the blocked area. The angle of curves in dammed area is perpendicular as well as vertical. There is chance of drainage of the glacier lake slowly through these curves in summer season (May and June) 2019. The slope of dammed area is 5-25 while the slope is lake area is more the 25 degree. This shows that the pressure of lake water on glacier blockage area will be increase day by day. After the Analysis of curves of dammed area, glacier advancement, Slope and solar Isolation on glacier and blocked area it is conclude that the advancement will be continues and lake will be drain through the curves. This advancement may damage the irrigation channel of Aliabad Hunza and Power House in short term while there may be chance of glacier lake outburst flood (GLOF) in long term scenario. In summer the temperature of lake water will be slightly increase as compare to the glacier ice of blocked area. So there is need of proper monitoring of Shispar glacier through remote sensing, Helicopter, UAV and field surveying to generate early warning alert to downstream community. 


\section{Acknowledgment}

The authors acknowledge that over heartiest and special gratitude to Muhammad Sheraz and Umair for help and thanks to Zameer Abbas who help me during field data collection of Shispar glacier.

\section{Competing interests}

The authors declare that they have no competing interests with respect to the research, authorship or publications of this article.

\section{References}

[1] Altena, B. and Kaab, A.: Weekly Glacier Flow Estimation from Dense Satellite Time Series Using Adapted Optical Flow Technology, Front. Earth Sci., 5, 1-12, https://doi.org/10.3389/feart.2017.00053.

[2] Bolch, T., Pieczonka, T., Mukherjee, K., and Shea, J.: Brief communication: Glaciers in the Hunza catchment (Karakoram) have been nearly in balance since the 1970s, The Cryosphere, 11, 531- 539, https://doi.org/10.5194/tc-11-531-2017.

[3] Clarke, G. K. C., Collins, S. G., and Thompson, D. E.: Flow, thermal structure, and subglacial conditions of a surge-type glacier, Can. J. Earth Sci., 21, 232-240, https://doi.org/10.1139/e84-024.

[4] Copland, L., Sylvestre, T., Bishop, M. P., Shroder, J. F., Seong, Y. B., Owen, L. A., Bush, A., and Kamp, U.: Expanded and Recently Increased Glacier Surging in the Karakoram, Arct. Antarct. Alp. Res., 43, 503-516, https://doi.org/10.1657/1938-4246-43.4.503.

[5] Damsgaard, A., Egholm, D. L., Piotrowski, J. A., Tulaczyk, S., Larsen, N. K., and Brædstrup, C. F.: A new methodology to simulate subglacial deformation of water-saturated granular material, The Cryosphere, 9, 2183-2200, https://doi.org/10.5194/tc-9-2183-2015.

[6] F Frey, H., Machguth, H., Huss, M., Huggel, C., Bajracharya, S., Bolch, T., Kulkarni, A., Linsbauer, A., Salzmann, N., and Stoffel, M.: Estimating the volume of glaciers in the Himalayan Karakoram region using different methods, The Cryosphere, 8, 2313-2333, https://doi.org/10.5194/tc-82313-2014.

[7] Hewitt, K. and Liu, J.: Ice-Dammed Lakes and Outburst Floods, Karakoram Himalaya: Historical Perspectives on Emerging Threats, Phys. Geogr., 31, 528-551, https://doi.org/10.2747/0272-3646.31.6.528.

[8] Hussain, A.; Sagin, J.; Chun, K.P. A Remote Sensing Contribution to Flood Modelling in an Inaccessible Mountainous River Basin. Preprints 2018 , 2018100650 https://doi.org/10.20944/preprints201810.0650.v1.

[9] Hussain, A. 2019. Temporal monitoring of ghamu bar glacial lakes using remote sensing and GIS. International Journal of Advance Geoscience. (https://www.researchgate.net/Publication/332981010. https://doi.org/10.14419/ijag.v7i1.20308.

[10] Iturrizaga, L.: New observations on present and prehistorical glacier-dammed lakes in the Shimshal valley (Karakoram Mountains), J. Asian Earth Sci., 25, 545-555, https://doi.org/10.1016/j.jseaes.2004.04.011.

[11] Kamb, B.: Glacier surge mechanism based on linked cavity configuration of the basal water conduit system, J. Geophys. Res., 92, 9083-9100, https://doi.org/10.1029/JB092iB09p09083.

[12] Kääb, A., Treichler, D., Nuth, C., and Berthier, E.: Brief Communication: Contending estimates of 2003-2008 glacier mass balance over the PamirKarakoram-Himalaya, The Cryosphere, 9, 557- 564, https://doi.org/10.5194/tc-9-557-2015.

[13] Mayer, C., Fowler, A. C., Lambrecht, A., and Scharrer, K.: A surge of North Gasherbrum Glacier, Karakoram, China, J. Glaciol., 57, 904-916, https://doi.org/10.3189/002214311798043834.

[14] Paul, F.: Revealing glacier flow and surge dynamics from animated satellite image sequences: examples from the Karakoram, The Cryosphere, 9, 2201-2214, https://doi.org/10.5194/tc-9-2201-2015.

[15] Paul, F., Strozzi, T., Schellenberger, T., and Kääb, A.: The 2015 Surge of Hispar Glacier in the Karakoram, Remote Sens., 9, 888, https://doi.org/10.3390/rs9090888.

[16] Quincey, D. J. and Luckman, A.: Brief Communication: On the magnitude and frequency of Khurdopin glacier surge events, The Cryosphere, 8 , 571-574, https://doi.org/10.5194/tc-8-571-2014.

[17] Quincey, D. J., Braun, M., Glasser, N. F., Bishop, M. P., Hewitt, K., and Luckman, A.: Karakoram glacier surge dynamics, Geophys. Res. Lett., 38, 1-6, https://doi.org/10.1029/2011GL049004.

[18] Rankl, M., Kienholz, C., and Braun, M.: Glacier changes in the Karakoram region mapped by multimission satellite imagery, The Cryosphere, 8 , 977-989, https://doi.org/10.5194/tc-8-977-2014.

[19] Round, V., Leinss, S., Huss, M., Haemmig, C., and Hajnsek, I.: Surge dynamics and lake outbursts of Kyagar Glacier, Karakoram, The Cryosphere, 11, 723-739, https://doi.org/10.5194/tc-11-723-2017.

[20] Sevestre, H. and Benn, D. I.: Climatic and geometric controls on the global distribution of surge-type glaciers: Implications for a unifying model of surging, J. Glaciol., 61, 646-662, https://doi.org/10.3189/2015JoG14J136.

[21] Shean, D. E., Alexandrov, O., Moratto, Z. M., Smith, B. E., Joughin, I. R., Porter, C., and Morin, P.: An automated, open-source pipeline for mass production of digital elevation models (DEMs) from very-high-resolution commercial stereo satellite imagery, ISPRS Journal of Photogrammetry and Remote Sensing, 116, 101-117, https://doi.org/10.1016/j.isprsjprs.2016.03.012.

[22] Steiner, J., Kraaijenbrink, P., and Immerzeel, W.: Velocity and Volume Change Data for the Khurdopin Glacier Surge 2017, Mendeley Data, v1. 